\title{
PERANCANGAN MODEL SERVICE ORIENTED ARCHITECTURE PADA PROSES PRODUKSI OBAT BERDASARKAN CARA PEMBUATAN OBAT YANG BAIK
}

\author{
Muhammad A Makky', Rahmat Yasirandi² \\ ${ }^{1,2}$ Fakultas Informatika, Universitas Telkom \\ ${ }^{1}$ malmakky@telkomuniversity.ac.id, 2batanganhitam@telkomuniversity.ac.id
}

(Naskah masuk: 3 Maret 2021, diterima untuk diterbitkan: 1 April 2021)

\begin{abstract}
Abstrak
Organisasi industri farmasi pada proses produksi obat dan bahan obat berupaya untuk melakukan monitoring operasional kegiatan mengenai kerusakan mesin, persediaan, perubahan mixed product, meminimalkan kemacetan produksi, dan penjadwalan pesanan bekerja melalui pabrik. Selain itu, diharapkan konsep green environment pada proses produksi obat dan bahan obat dapat meminimalisasi konsumsi kertas. Dalam hal ini, teknologi data (TI) mampu digunakan dalam proses perencanaan dan pengendalian kualitas produk, dan teknologi data dapat digunakan dalam fungsi pengendalian persediaan dan pendistribusian laporan untuk semua proses bisnis dalam organisasi. Tidak hanya itu, integrasi TI bertujuan untuk memadukan sistem data yang sebelumnya terpisah untuk menciptakan energi data yang lebih lengkap dan adil bagi organisasi industri farmasi. Namun, jumlah dana atau anggaran yang dibutuhkan untuk menerapkan teknologi dan biaya pemeliharaannya menjadi masalah. Service Oriented Architecture ( SOA) ialah pemecahan alternatif buat menanggulangi masalah- masalah pada industri industri farmasi. SOA menawarkan suatu infrastruktur yang tepat dengan keahlian integrasi yang telah terkelola, serta pastinya hendak berakibat pada meningkatnya reliability, kemudahan pertukaran data antar aplikasi, kurangi pengaruh bila terjalin pergantian, serta pasti bisa memencet biaya- biaya buat keperluan integrasi serta modifikasi aplikasi. Model rancangan SOA dibuat mengikuti proses bisnis proses produksi obat dan bahan obat yang didasari oleh dokumen pedoman Cara Pembuatan Obat yang Baik (CPOB). Hasil membuktikan bahwa rancangan SOA dapat digunakan untuk membangun aplikasi proses produksi obat dan bahan obat serta dapat menjadi layanan untuk sistem lain bertukar data.
\end{abstract}

Kata kunci: Industri Farmasi, Proses Produksi Obat dan Bahan Obat, $C P O B, S O A$

\section{THE MODEL OF SERVICE ORIENTED ARCHITECTURE FOR DRUG PRODUCTION PROCESS BASED ON GOOD MANUFACTURING PRACTICE (GMP) DOCUMENT}

\begin{abstract}
Organizations of the pharmaceutical industry on the manufacturing of medicine and medicinal materials endeavored to monitor the operational activities concerning to machinery damage, inventory, product mix changes, minimize congestion production, and scheduling of work orders through the factory. In addition, it is expected the concept of green environment on the manufacturing of medicine and medicinal materials can minimize paper consumption. In this case, information technology (IT) can be used in the scheduling process, perform products quality control, as well as play a role in regulating supply and deliver a report on the entire business processes that occur within the organization. In addition, the integration of IT aims to combine the previously separate information systems to an information resource that is more completely and comprehensively for the pharmaceutical industry organizations. However, the amount of funds or a budget needed to implement technology to finance its maintenance becomes a problem. Service Oriented Architecture (SOA) is an alternative solution to solve the problems on the company's pharmaceutical industry. SOA offers a good infrastructure with integration capabilities that have been managed, and will certainly have an impact on the increased reliability, ease of information exchange between applications, reducing the impact if there is change, and it certainly can reduce the costs for the integration and modification of applications. SOA design model is created to follow the business process of manufacturing of medicine and medicinal materials are based on the guidance Good Manufacturing Practice (GMP document). The results prove that the design of SOA can be used to build $v$ the application of manufacturing of medicine and medicinal materials and may be a service to other systems for data exchange.
\end{abstract}

Keywords: Pharmaceutical Industry, Manufacturing for Medicine and Medicinal Materials, GMP, SOA 


\section{PENDAHULUAN}

Kebutuhan teknologi informasi (TI) di dalam industri manufaktur diantaranya untuk Manufacturing Resource Planning (MRP), Financial System, Production Planning, Scheduling, Distribution Requirements Planning (DRP), Quality Management, Human Resource Management, dan berbagai aktivitas proses lainnya [1]. anufaktur biasanya merupakan industri padat modal dan memiliki rasio leverage operasi yang besar (rasio antara kompensasi tetap dan kompensasi variabel total). Sebagai industri padat modal, industri manufaktur harus menekan upah mengambang. Industri farmasi yang terdaftar di salah satu industri manufaktur telah memposisikan TI sebagai pendukung strategi bisnis untuk mencapai tujuan, dan memposisikannya sebagai alat yang menghasilkan proses bisnis terintegrasi yang dapat menampilkan data terkini [2]. Harapannya dengan dukungan IT ini, industri mampu bersaing dalam dunia bisnis. Adanya TI yang baik, sesuai dan tepat akan sangat mendukung upaya mewujudkan visi dan misi industri. Diharapkan TI dapat berbagi dukungan untuk menyediakan informasi dan data yang terintegrasi kepada seluruh unit bisnis yang terkait. Tidak hanya itu, TI juga dapat digunakan untuk memantau kegiatan operasional dan menganalisis kondisi industri. Integrasi sistem data bertujuan untuk menggabungkan sistem data yang sebelumnya dipisahkan untuk menyediakan energi data yang lebih lengkap dan terdistribusi secara merata kepada organisasi. Selain itu, TI mendukung konsep green environment pada proses produksi yang dapat meminimalisasi konsumsi kertas. Masalah organisasi industri farmasi untuk menyatukan fungsi dalam mengelola aspek desain, kualitas, proses produksi, SDM, strategi proses, strategi lokasi, strategi layout, SCM, inventory management, scheduling, dan maintenance. Di antaranya terdapat banyak keputusan yang tertunda karena decision flow yang terhambat. Selain itu, dibutuhkan dana yang cukup besar untuk mengimplementasikan teknologi dalam menangani berbagai macam masalah. TI digunakan secara konseptual dalam proses penjadwalan, melakukan pengendalian tentang kualitas produk, berperan dalam mengatur persediaan dan memberikan laporan mengenai seluruh bisnis proses yang terjadi dalam organisasi. Sebuah sistem yang terintegrasi mampu menyajikan informasi yang terbaru. Keberadaan asset TI mampu menjadi dukungan yang tepat untuk visi dan misi sebuah organisasi bisnis [3]. Namun di balik itu semua, muncul permasalahan baru, yaitu terkait pengadaan asset baru dalam menerapkan IT, terlebih terakit pemeliharan dan sumber daya manusia yang tidak sederhana. Cloud computing mampu memberikan solusi yang mampu menyesuaikan kemampuan perusahaan [4]. Cloud computing dapat memberikan penurunan investasi IT terutama terakit infrastruktur dan pengadaan fisik tempat penyimpanan data/ server [5]. Penanggulangan resiko investasi dapat terwujud dengan membebankan kemunculan resiko pada pihak ketiga [6], [7]. Pada umumnya perusahaan selalu memnjadikan pengadaan aplikasi yang tumpeng tindih, menutupi lubang yang ada namun membuka lubang yang lain, salah satu penyebabnya adalah tidak adanya standar dalam pengembangan yang diakibatkan perbedaan vendor. Masalah integrasi ini memang telah menjelma menjadi isu yang serius. Namun itu bisa tak terwujud dalam arsitektur SOA. Aplikasi pada SOA dibangun berdasar layanan. Layanan merupakan implementasi dari fungsi bisnis yang terdefinisi jelas dan dapat dikonsumsi oleh pengguna pada berbagai aplikasi atau proses bisnis. SOA membantu organisasi perangkat lunak agar dapat melakukan proses bisnis secara lebih efisien, beradaptasi terhadap perubahan dan kompetisi serta memungkinkan konsep perangkat lunak sebagai layanan. Dengan memanfaatkan SOA merupakan solusi alternatif untuk mengatasi masalahmasalah pada perusahaan industri farmasi [8], [9].

\section{METODE PENELITIAN}

Bagian ini dijelaskan mengenai metoda yang dilakukan saat penelitian, tempat dan waktu penelitian, serta langkah-langkah kerja yang dilakukan selama penelitian. Jenis penelitian yang diadopsi dari metode A Design Science Research Methodology for Information Systems Research[10]. Tahapan-tahapan menurut Design Science Research Methodology yang dipakai adalah sampai tahap Design and Development. Dan lebih lengkapnya adalah sebagai berikut:

1. Identify Problem and Motivate, Pada tahapan ini dilakukan pendefinisian masalah yang ada dan solusi dari masalah tersebut. Solusi didefinisikan dalam bentuk rancangan model, arsitektur teknologi dan prototype aplikasi.

2. Objective of the Solution, Tahapan ini menyimpulkan tujuan dari solusi masalah yang ada. Tujuan adalah tahap akhir yang ingin dicapai pada penelitian ini.

3. Design and Development, Tahapan ini meliputi penentuan desain untuk memecahkan permasalahan dan kemudian melakukan pengembangan desain tersebut. Analisis dan desain yang dibuat berdasarkan SOA Delivery Life Cycle [11]. Hasil rancangan kemudian dibuat prototype aplikasinya.

\subsection{Cara Pembuatan Obat yang Baik (CPOB)}

CPOB merupakan pedoman untuk semua rangkaian prosedur di industri farmasi dalam 
produksi obat jadi, sesuai dengan keputusan Menteri Kesehatan RI No. 43/Menkes/SK/II/1988 tentang Cara Pembuatan Obat yang BaikPedoman CPOB dirancang untuk menciptakan produk obat yang masih memenuhi persyaratan mutu yang telah ditetapkan secara formal agar sesuai dengan peruntukannya. Perkembangan pesat teknologi farmasi telah menyebabkan perubahan cepat dalam konsep dan persyaratan CPOB. Konsep CPOB yang bersifat dinamis perlu disesuaikan dari waktu ke waktu untuk mengeksplorasi perkembangan teknologi di bidang farmasi. Aspek-aspek yang dilindungi dalam CPOB tahun 2006 meliputi 12 Butir [13], yaitu:

1. Manajemen Mutu

2. Personalia

3. Bangunan dan Fasilitas

4. Peralatan

5. Sanitasi dan Higiene

6. Produksi

7. Pengawasan Mutu

8. Inspeksi Diri dan Audit Mutu

9. Penanganan Keluhan Terhadap Produk, Penarikan Kembali Produk dan Produk Kembalian

10. Dokumentasi

11. Pembuatan dan Analisis Berdasarkan Kontrak

12. Kualifikasi dan Validasi

Ditambah dengan terdapat 7 proses yang bersifat suplemen, yaitu:

1. Pembuatan Produk Steril,

2. Pembuatan Produk Biologi,

3. Pembuatan Gas Medisinal,

4. Pembuatan Inhalasi Dosis Terukur Bertekanan (Aerosol)

5. Pembuatan Produk Darah,

6. Pembuatan Obat Investigasi Untuk Uji Klinik, dan

7. Sistem Komputerisasi.

\section{HASIL DAN PEMBAHASAN}

\subsection{Masalah Proses Produksi Industri Farmasi}

Berdasarkan hasil observasi dan wawancara[14], didapatkan data permasalahan menjadi tiga (3) kategori, yaitu monitoring, efisiensi, dan stok. Poin-poin dari setiap kategori ini adalah sebagai berikut:

- Monitoring

- Manajer Produksi dan Manager Perencanaan tidak dapat melihat aktivitas mesin yang sedang digunakan.
- Manajer Produksi dan Manager Perencanaan tidak mendapatkan informasi kerusakan mesin secara real time.

- $\quad$ Efisiensi

- Manual memakai media kertas (1 batch proses $=500$ lembar form).

- Dalam perencanaan proses produksi, setiap Person In Charge (PIC) bersifat menunggu dari divisi bagian lain.

- $\quad$ Stok

- Holding tidak dapat melihat stok yang tersedia di gudang secara real time.

- Plant Manager harus melaporkan data stok termutakhir secara manual melalui pengiriman email.

\subsection{Analisis Kebutuhan}

Tahap pertama adalah pemahaman terhadap proses bisnis yang terjadi pada industri farmasi. Pada saat perencanaan akan ditelaah terlebih dahulu mencukupi atau tidaknya stok bahan produksi dan bahan kemas di gudang. Apabila stok tidak cukup maka dilakukan proses pembelian bahan ke bagian pembelian. Setelah bahan awal dan bahan kemas serta perencanaan telah siap, tahapan selanjutnya adalah proses produksi hingga barang jadi. Barang jadi atau produk yang telah selesai diproduksi disimpan di dalam gudang sebagai stok obat jadi siap kirim. Sesuai dengan bahasan pada penelitian ini yakni hanya pada bagian proses produksi maka untuk selanjutnya dijelaskan mengenai proses yang terjadi pada proses produksi industri farmasi. Proses produksi ini mencakup dari mulai penimbangan bahan awal hingga ke proses karantina obat jadi dan pengemasan.

\subsubsection{Rantai Nilai}

Rantai nilai menggambarkan rangkaian proses pada suatu bisnis yang menghasilkan suatu nilai. Pada Gambar 1 dapat dilihat rantai nilai dari proses produksi industri farmasi. Rantai nilai proses produksi diawali oleh tahap persiapan dari persediaan bahan baku dan bahan kemas. Setelah bahan siap maka masuk ke tahap pengolahan obat dan pengendalian mutu dari setiap fase produksi. Setelah produk selesai dibuat maka akan dikarantina hingga pengemasan siap. Apabila produk selesai dikemas, hal ini berarti produk disebut sebagai produk jadi. Produk jadi dimasukkan ke logistik gudang penyimpanan produk jadi dan siap untuk didistribusikan. 


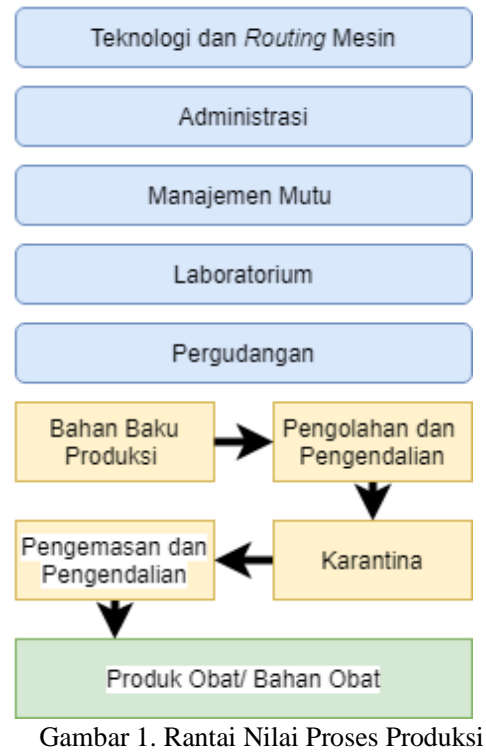

\subsubsection{Identifikasi Kebutuhan Data}

\begin{tabular}{|c|c|}
\hline Stakeholder & Keterlibatan \\
\hline Manajer Pabrik & $\begin{array}{l}\text { 1. Membuat perencanaan produksi } \\
\text { 2. Membuat perintah kerja produksi } \\
\text { 3. Membuat perintah kerja kemas } \\
\text { 4. Memonitor aktifitas kerja produksi } \\
\text { 5. Memonitor kegiatan mesin yang } \\
\text { digunakan pada proses produksi }\end{array}$ \\
\hline $\begin{array}{l}\text { Manajer } \\
\text { Produksi }\end{array}$ & $\begin{array}{l}\text { 1. Melakukan penyusunan rencana produksi } \\
\text { 2. Memonitor proses produksi } \\
\text { 3. Memonitor kegiatan mesin yang } \\
\quad \text { digunakan pada proses produksi } \\
\text { 4. Meminta dan menerima bahan baku } \\
\text { 5. Melakukan karantina produk } \\
\text { 6. Melakukan penyusunan rencana } \\
\text { pengemasan } \\
\text { 7. Meminta dan menerima bahan kemas } \\
\text { 8. Mengirim memo pemeriksaan produk jadi } \\
\text { 9. Mengirim memo penyimpanan produk } \\
\text { jadi }\end{array}$ \\
\hline $\begin{array}{l}\text { Manajer } \\
\text { Pengawasan } \\
\text { Mutu }\end{array}$ & $\begin{array}{l}\text { 2. Memastikan racikan produk sesuai dengan } \\
\text { kualitas mutu } \\
\text { 3. Memastikan ruangan kerja produksi dan } \\
\text { kemas dalam keadaaan layak pakai } \\
\text { 4. Melakukan pengendalian produk } \\
\text { 5. Memberikan status produk sesuai dengan } \\
\text { spesifikasi } \\
\text { 6. Memberikan status racikan produk sesuai } \\
\text { dengan kualitas mutu } \\
\text { 7. Memberikan status ruangan kerja produksi } \\
\text { dan kemas dalam keadaan layak pakai }\end{array}$ \\
\hline $\begin{array}{l}\text { Supervisor } \\
\text { Penimbangan }\end{array}$ & $\begin{array}{l}\text { 1. Menerima perintah kerja dan daftar bahan } \\
\text { baku }\end{array}$ \\
\hline
\end{tabular}

2. Melakukan penimbangan bahan baku sesuai dengan spesifikasi
3. Memberikan status penimbangan bahan baku

STBK

1. Meminta dan menerima bahan kemas

2. Melakukan penandaan bahan kemas

3. Melakukan pengecekan bahan kemas sesuai dengan kebutuhan kemas

4. Memberikan status pengecekan bahan kemas

Subbab ini dijelaskan mengenai kebutuhan data yang dibutuhkan untuk perancangan. Kebutuhan data dimulai dari pendefinisian keinginan stakeholder lalu diselaraskan dengan solusi permasalahan. Stakeholder pada proses produksi ini terdapat lima (5), yaitu:

1. Manajer Pabrik

2. Manajer Produksi

3. Manajer Pengawasan Mutu

4. Supervisor Penimbangan

5. Supervisor Penandaan Bahan Kemas (STBK)

\subsubsection{Rekomendasi Solusi Permasalahan}

Dari hasil observasi dan pengamatan maka penulis merekomendasikan solusi yang dapat mengatasi permasalahan yang dijelaskan pada bab 3.1. Rekomendaasi ini dapat dilihat pada Tabel 2 di bawah ini:

Tabel 2. Rekomendasi Solusi Permasalahan

\begin{tabular}{|c|c|}
\hline Masalah & Strategi Solusi \\
\hline $\begin{array}{l}\text { Manajer Produksi dan Plant } \\
\text { Manager tidak dapat melihat } \\
\text { aktifitas mesin yang sedang } \\
\text { digunakan. }\end{array}$ & $\begin{array}{l}\text { Integrasi data aktifitas } \\
\text { mesin dengan sistem. }\end{array}$ \\
\hline $\begin{array}{l}\text { Manajer Produksi dan Plant } \\
\text { Manager tidak mendapatkan } \\
\text { informasi kerusakan mesin secara } \\
\text { real time. }\end{array}$ & $\begin{array}{l}\text { Penanganan } \\
\text { infrastruktur dan } \\
\text { pencatatan data mesin } \\
\text { ke dalam sistem. }\end{array}$ \\
\hline $\begin{array}{l}\text { Manual memakai media kertas ( } 1 \\
\text { batch proses }=500 \text { lembar form). }\end{array}$ & $\begin{array}{l}\text { Penggunaan teknologi } \\
\text { informasi secara } \\
\text { optimal. }\end{array}$ \\
\hline $\begin{array}{l}\text { Dalam perencanaan proses } \\
\text { produksi, setiap PIC bersifat } \\
\text { menunggu dari divisi bagian lain. }\end{array}$ & $\begin{array}{l}\text { Data terintegrasi untuk } \\
\text { tersedia informasi yang } \\
\text { akurat. }\end{array}$ \\
\hline $\begin{array}{l}\text { Holding tidak dapat melihat stok } \\
\text { yang tersedia di gudang secara real } \\
\text { time. } \\
\text { Plant Manager harus melaporkan } \\
\text { data stok termutahir secara manual } \\
\text { melalui pengiriman email }\end{array}$ & $\begin{array}{l}\text { Menyediakan layanan } \\
\text { yang dapat memberikan } \\
\text { informasi uptodate. } \\
\text { Teknologi digunakan } \\
\text { sesuai dengan } \\
\text { kebutuhan. }\end{array}$ \\
\hline
\end{tabular}

\subsection{Perancangan Services}

\subsubsection{Identifikasi Otomasi Sistem}

Subbab ini dilakukan identifikasi dari proses bisnis yang akan diotomatisasi. Aktivitas-aktivitas yang dapat diotomatisasi dijelaskan pada Tabel 3 sebagai berikut: 
Tabel 3. Otomatisasi Aktifitas

\begin{tabular}{|c|c|c|}
\hline No & Aktifitas & $\begin{array}{c}\text { Dapat } \\
\text { Diotomatisasi }\end{array}$ \\
\hline 1 & Membuat perencanaan produksi & Tidak \\
\hline 2 & Membuat perintah kerja produksi & Ya \\
\hline 3 & Membuat perintah kerja kemas & Ya \\
\hline 4 & Memonitor aktifitas kerja produksi & Tidak \\
\hline 5 & $\begin{array}{l}\text { Memonitor kegiatan mesin yang digunakan } \\
\text { pada proses } \\
\text { produksi }\end{array}$ & Ya \\
\hline 6 & Melakukan penyusunan rencana produksi & Tidak \\
\hline 7 & Memonitor proses produksi & Tidak \\
\hline 8 & $\begin{array}{l}\text { Memonitor kegiatan mesin yang digunakan } \\
\text { pada proses produksi }\end{array}$ & Ya \\
\hline 9 & Meminta dan menerima bahan baku & Ya \\
\hline 10 & Melakukan karantina produk & Tidak \\
\hline 11 & $\begin{array}{l}\text { Melakukan penyusunan rencana } \\
\text { pengemasan }\end{array}$ & Tidak \\
\hline 12 & Meminta dan menerima bahan kemas & Ya \\
\hline 13 & Mengirim memo pemeriksaan produk jadi & Ya \\
\hline 14 & Mengirim memo penyimpanan produk jadi & Ya \\
\hline 15 & Memastikan produk sesuai spesifikasi & Tidak \\
\hline 16 & $\begin{array}{l}\text { Memastikan racikan produk sesuai dengan } \\
\text { kualitas mutu }\end{array}$ & Tidak \\
\hline 17 & $\begin{array}{l}\text { Memastikan ruangan kerja produksi dan } \\
\text { kemas dalam keadaaan layak pakai }\end{array}$ & Tidak \\
\hline 18 & Melakukan pengendalian produk & Tidak \\
\hline 19 & $\begin{array}{l}\text { Memberikan status produk sesuai dengan } \\
\text { spesifikasi }\end{array}$ & Ya \\
\hline 20 & $\begin{array}{l}\text { Memberikan status racikan produk sesuai } \\
\text { dengan kualitas mutu }\end{array}$ & Ya \\
\hline 21 & $\begin{array}{l}\text { Memberikan status ruangan kerja produksi } \\
\text { dan kemas dalam keadaan layak pakai }\end{array}$ & Ya \\
\hline 22 & $\begin{array}{l}\text { Menerima perintah kerja dan daftar bahan } \\
\text { baku }\end{array}$ & Ya \\
\hline 23 & $\begin{array}{l}\text { Melakukan penimbangan bahan baku sesuai } \\
\text { dengan spesifikasi }\end{array}$ & Tidak \\
\hline 24 & $\begin{array}{l}\text { Memberikan status penimbangan bahan } \\
\text { baku }\end{array}$ & Ya \\
\hline 25 & Meminta dan menerima bahan kemas & Ya \\
\hline 26 & Melakukan penandaan bahan kemas & Tidak \\
\hline 27 & $\begin{array}{l}\text { Melakukan pengecekan bahan kemas sesuai } \\
\text { dengan kebutuhan kemas }\end{array}$ & Tidak \\
\hline 28 & $\begin{array}{l}\text { Memberikan status pengecekan bahan } \\
\text { kemas }\end{array}$ & Ya \\
\hline
\end{tabular}

\subsubsection{Layanan Bisnis}

Proses bisnis yang dijelaskan di subbab sebelumnya, terlihat bahwa pemakaian kertas dan alur kerja yang masih banyak berhubungan antar entitas sehingga dapat mengakibatkan bertambahnya waktu pengerjaan dan konsumsi kertas yang tinggi[15]. Selain itu, untuk meningkatkan otomatisasi dan efisiensi kerja maka diperlukan reengineering proses bisnis. Dari sisi re-engineering ini dapat tergambarkan bagaimana bentuk dari sistem yang akan dibangun. Maka ditawarkan solusi alur kerja seperti yang dapat dilihat pada Gambar 2 mengenai alur proses pengolahan dan pengendalian produksi dan Gambar 3 mengenai pengemasan dan pengendalian produksi.

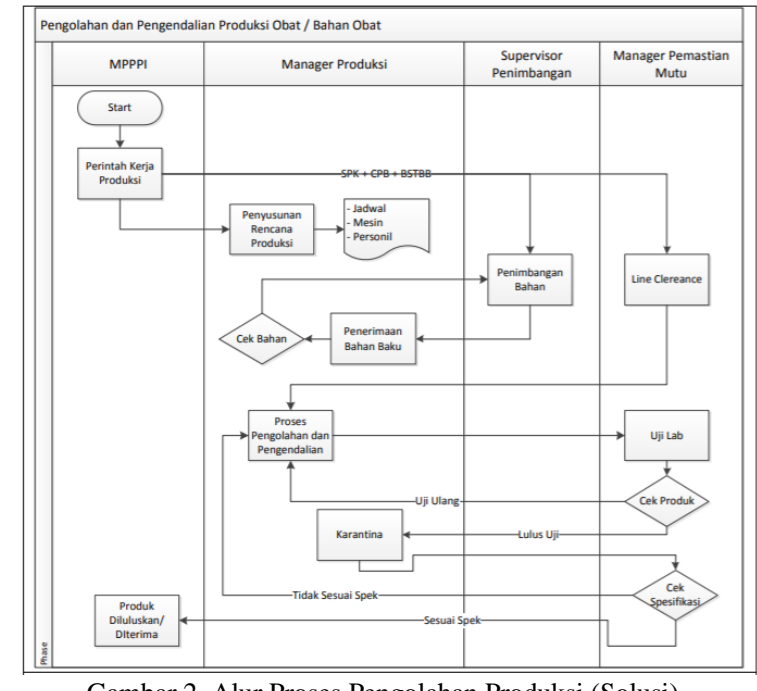

Gambar 2. Alur Proses Pengolahan Produksi (Solusi)

Terlihat bahwa dengan solusi yang ditawarkan dapat melakukan efisiensi dengan mendistribusikan perintah kerja langsung ke setiap divisi. Selain itu, dengan berkurangnya konsumsi kertas maka peminimalan penggunaan kertas untuk menuju produksi green environment terpenuhi.

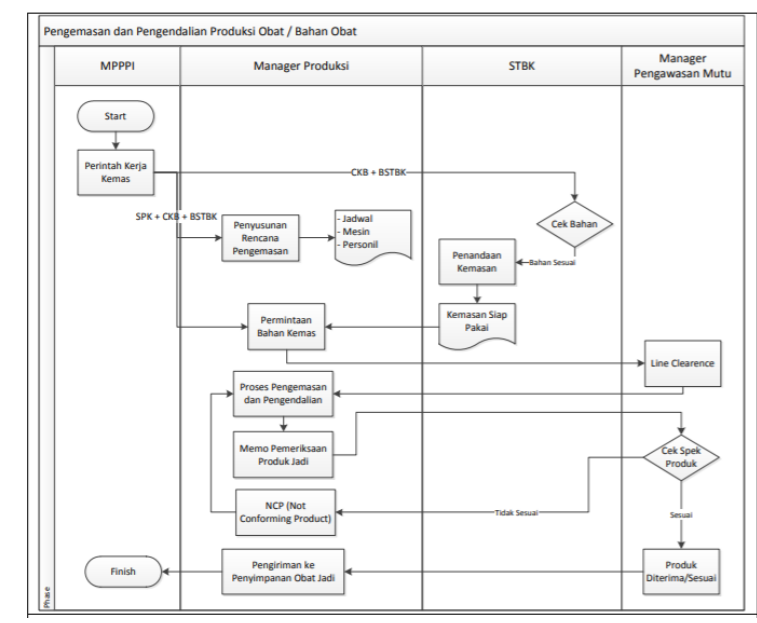

Gambar 3. Alur Proses Pengemasan Produksi (Solusi)

\subsubsection{Layanan Aplikasi}

Bagian ini membahas mengenai struktur dan desain layanan dari sistem yang dikembangkan untuk mengeksplorasi proses bisnis yang ada, kemudian dilanjutkan dengan desain SOA. Penjelasan struktur dan desain layanan akan dijelaskan melalui diagram use case, sedangkan desain SOA dilakukan dengan mengidentifikasi calon layanan dan bandnya. Diagram use case ditentukan berdasarkan persyaratan fungsional. Kasus penggunaan memenuhi persyaratan penggunaan ini. Selanjutnya, use case memberikan hasil kepada peserta. Berikut adalah pemetaan model pelayanan, partisipan dan use case dalam model proses pembuatan industri farmasi yang dirinci berdasarkan partisipan seperti pada gambar dibawah. 


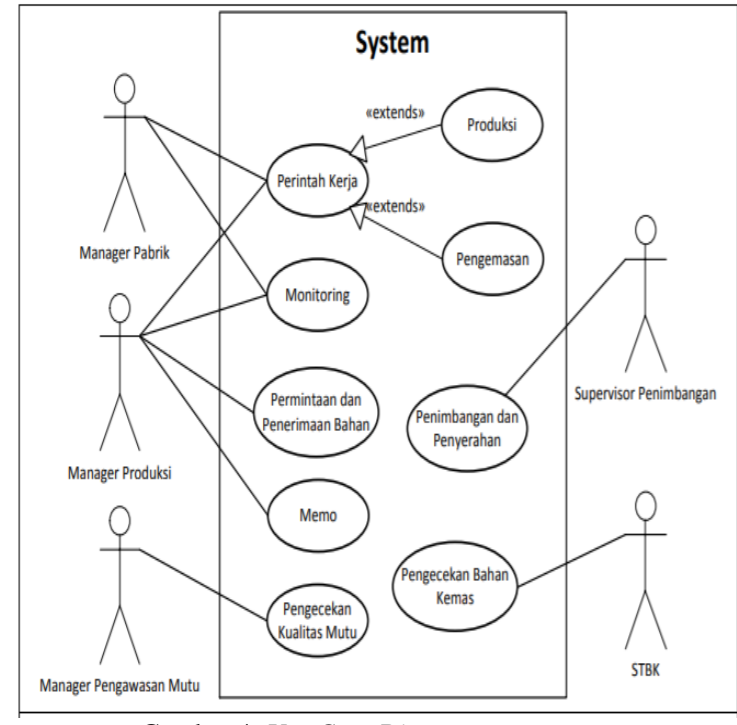

Gambar 4. Use Case Diagram

Untuk penjelasan dari use case diagram pada Gambar 4. dapat dilihat pada Tabel 4 di bawah ini.

Tabel 4. Penjelasan Use Case Diagram

\begin{tabular}{|c|c|}
\hline Use Case & Keterangan \\
\hline Perintah Kerja & Modul ini digunakan untuk \\
\hline Produksi & $\begin{array}{l}\text { memerintahkan pengerjaan produksi obat } \\
\text { atau bahan obat. }\end{array}$ \\
\hline Perintah Kerja & Modul ini digunakan untuk \\
\hline Kemas & $\begin{array}{l}\text { memerintahkan pengerjaan pengemasan } \\
\text { obat atau bahan obat. }\end{array}$ \\
\hline Monitoring & $\begin{array}{l}\text { Modul ini digunakan untuk mengetahui } \\
\text { data stok dan mesin secara real time. }\end{array}$ \\
\hline Permintaan dan & Modul ini digunakan untuk melakukan \\
\hline Penerimaan Bahan & $\begin{array}{l}\text { permintaan dan penerimaan bahan } \\
\text { produksi maupun bahan kemas }\end{array}$ \\
\hline Memo & $\begin{array}{l}\text { Modul ini digunakan untuk permintaan } \\
\text { pemeriksaan produk jadi maupun } \\
\text { penyimpanan ke gudang penyimpanan } \\
\text { produk jadi }\end{array}$ \\
\hline Penimbangan dan & Modul ini digunakan untuk melakukan \\
\hline Penyerahan & $\begin{array}{l}\text { serah terima barang untuk bahan awal } \\
\text { serta penimbangan bahan awal. }\end{array}$ \\
\hline Pengecekan & Modul ini digunakan untuk melakukan \\
\hline Kualitas Mutu & $\begin{array}{l}\text { pengecekan kesesuaian produk dengan } \\
\text { kualitas mutu. }\end{array}$ \\
\hline $\begin{array}{l}\text { Pengecekan Bahan } \\
\text { Kemas }\end{array}$ & $\begin{array}{l}\text { Modul ini digunakan untuk melakukan } \\
\text { pengecekan bahan kemas dengan } \\
\text { kebutuhan. }\end{array}$ \\
\hline
\end{tabular}

\section{Perancangan Basis Data}

Sistem yang dikembangkan menyangkut pengolahan dan penyimpanan data, perlu diperhitungkan juga bagaimana susunan penyimpanan data di dalam basis data sesuai kebutuhan sistem. Basis data yang dikembangkan terdiri dari tabel yang bersifat referensi, input, dan transaksi. Susunan tabel-tabel ini dapat dilihat pada Gambar 5

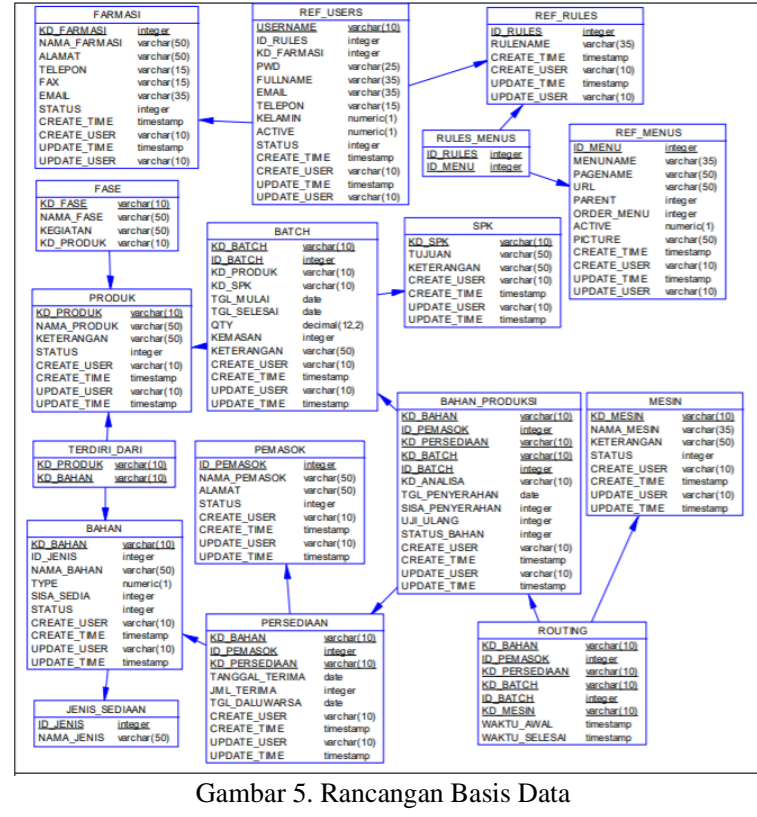

Penentuan Kandidat Service

Bagian ini dijelaskan mengenai identifikasi service pada setiap layer untuk mendukung pengembangan layanan perangkat lunak di proses produksi industri farmasi. Identifikasi service ini berdasarkan pada alur proses yang terdapat pada proses produksi obat dan bahan obat industri farmasi dan stok.

Berdasarkan pada sub bab bahasan proses bisnis dan rantai nilai maka didapat kandidat service pada layer orkestrasi adalah manufacturing pharmacy. Sedangkan identifikasi service pada layer bisnis terdapat tujuh (7) kandidat service. Dan pada layer aplikasi terdapat satu (1) kandidat service. Seluruh service ini dapat dilihat pada Gambar 6.

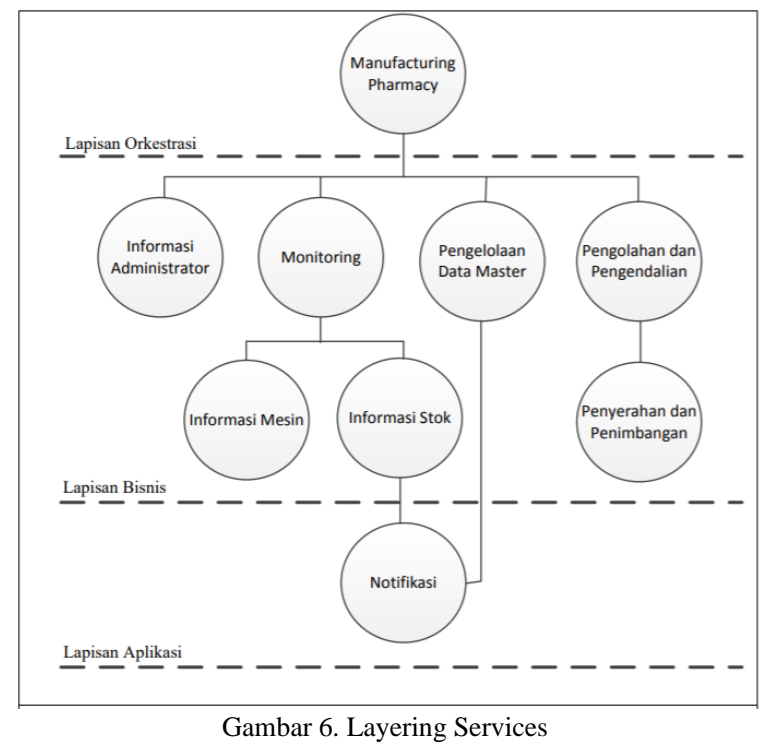

Setiap masing-masing layer service terdapat banyak operasi-operasi yang terkandung di dalamnya. Operasi ini adalah breakdown fungsi dari 
setiap service di atasnya. Untuk layer bisnis, operasioperasi yang ada adalah sebagai berikut:

\begin{tabular}{|c|c|}
\hline Bisnis Service & Operasi \\
\hline Informasi Administrator & $\begin{array}{l}\text { Data Pengguna } \\
\text { - } \text { addUser } \\
\text { - } \text { editUser } \\
\text { - } \text { deleteUser } \\
\text { - } \text { getAllUser } \\
\text { - } \text { getUserById } \\
\text { Data Peran } \\
\text { - } \text { addRole } \\
\text { - getRole } \\
\text { - } \text { deleteRole } \\
\text { - } \text { getAllRole } \\
\text { - getRoleById } \\
\text { Data Menu } \\
\text { - } \text { addMenu } \\
\text { - getMenu } \\
\text { - } \text { deleteMenu } \\
\text { - } \text { getAllMenu } \\
\text { - } \text { - } \text { deleteRoleMenu } \\
\text { - getMenuByRole }\end{array}$ \\
\hline $\begin{array}{l}\text { Pengelolaan Data } \\
\text { Master }\end{array}$ & 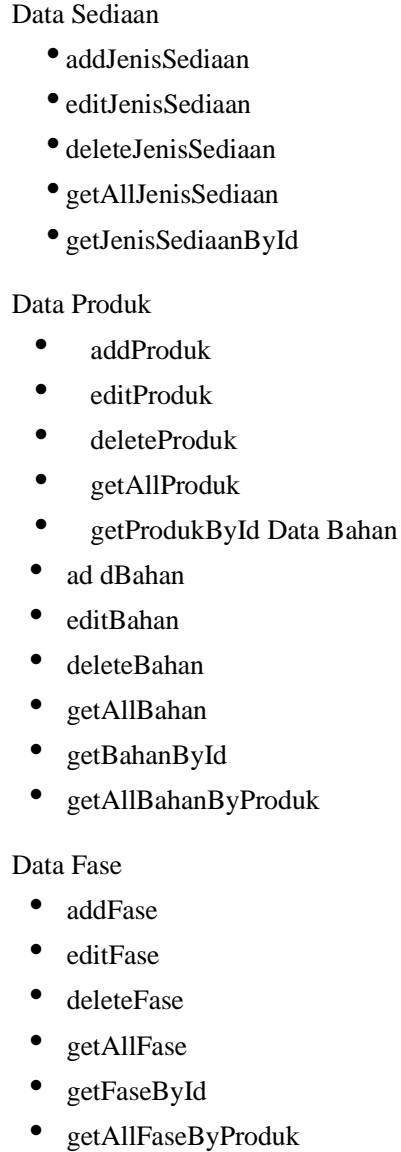 \\
\hline
\end{tabular}

- addPersediaan

- editPersediaan

- deletePersediaan

- getAllPersediaanByBahan

Data Mesin

- $\operatorname{addMesin}$

- editMesin

- deleteMesin

- getAllMesin

- getMesinById

Data Pemasok

- addPemasok

- editPemasok

- deletePemasok

- getAllPemasok

- getPemasokById

Data Batch

- addBatch

- editBatch

- deleteBatch

- getAllBatch

- getBatchById

- getAllBatchByStatus

Penyerahan dan Penimbangan

Data Bahan Awal dan Kemas

- getAllBahanByIdBatch

- getPemasokByIdBahan

- setStatusBahan

Informasi Mesin

Data Mesin dan Jadwal

- getAllMesinByStatus

- setMesinActive

Informasi Stok

Data Stok

- getStokProduk

- getStokIndent

Pengolahan dan Pengendalian

Data Mesin

- setMesinProduk

- getAllMesinByBatch

Data Bahan

- setStatusBahanAwal

- setStatusBahanKemas

Sedangkan untuk layer aplikasi, operasi-operasi yang ada adalah sebagai berikut:

Tabel 6. Operasi Layer Aplikasi

\begin{tabular}{lll}
\hline Aplikasi Service & Operasi \\
\hline Notifikasi & $\bullet$ & sendNotifikasiPerintahKerja \\
& $\bullet$ & sendNotifikasiUpdateStok
\end{tabular}

Data Persediaan Bahan 


\section{KESIMPULAN}

Rancangan model SOA telah berhasil diwujudkan. Kandidat-kandidat services yang telah dibuat berdasarkan hasil rancangan model memiliki keleluasaan dalam menentukan rancangan aplikasi serta memungkinkan untuk dimanfaatkan ulang secara konsisten. Pembuatan katalog services proses produksi obat dan bahan obat di industri farmasi dapat dimanfaatkan untuk pengembangan aplikasi dengan kemampuan untuk kolaborasi atau integrasi dengan sistem lain. Selain itu, katalog services memungkinkan pengembangan sistem aplikasi dengan berbagai macam bahasa pemrograman yang berbeda serta penggabungan beberapa platform untuk mengelola informasi yang sama.

\section{DAFTAR PUSTAKA}

[1] A. Barbu and G. Militaru, "Value Co-Creation between Manufacturing Companies and Customers. The Role of Information Technology Competency," Procedia Manuf., vol. 32, pp. 1069-1076, 2019, doi: 10.1016/j.promfg.2019.02.323.

[2] S. M. Chege, D. Wang, and S. L. Suntu, "Impact of information technology innovation on firm performance in Kenya," Inf. Technol. Dev., vol. 26, no. 2, pp. 316-345, Apr. 2020, doi: 10.1080/02681102.2019.1573717.

[3] S. De Haes, W. Van Grembergen, A. Joshi, and T. Huygh, "Enterprise Governance of IT, Alignment, and Value," 2020, pp. 1-13.

[4] S. Usman, M. Jamil, and A. Fuad, "Implementasi Teknologi Cloud Private Network Berbasis Teknologi Virtualisasi," JIKO (Jurnal Inform. dan Komputer), vol. 2, no. 2, pp. 56-60, 2018, doi: 10.33387/jiko.

[5] A. Fang, L. Cui, Z. Zhang, C. Chen, and Z. Sheng, "A Parallel Computing Framework for Cloud Services," in 2020 IEEE International Conference on Advances in Electrical Engineering and Computer Applications( AEECA), Aug. 2020, pp. 832-835, doi: 10.1109/AEECA49918.2020.9213468.

[6] R. Yasirandi, A. Lander, H. R. Sakinah, and I. M. Insan, "IoT Products Adoption for Smart Living in Indonesia: Technology Challenges and Prospects," in 2020 8th International Conference on Information and Communication Technology (ICoICT), Jun. 2020, pp. 1-6, doi: 10.1109/ICoICT49345.2020.9166200.

[7] A. Sunyaev, "Cloud Computing," in Internet Computing, Cham: Springer International Publishing, 2020, pp. 195-236.

[8] T. Erl, Service-Oriented Architecture: Concepts, Technology, and Design. NJ, United State: Prentice Hall PTR, 2005.

[9] Y. Wu, F. He, D. Zhang, and X. Li, "ServiceOriented Feature-Based Data Exchange for Cloud-Based Design and Manufacturing," IEEE
Trans. Serv. Comput., vol. 11, no. 2, pp. 341353, Mar. 2018, doi: 10.1109/TSC.2015.2501981

[10] K. Peffers, T. Tuunanen, M. A. Rothenberger, and S. Chatterjee, "A Design Science Research Methodology for Information Systems Research," J. Manag. Inf. Syst., vol. 24, no. 3, pp. 45-77, Dec. 2007, doi: 10.2753/MIS07421222240302.

[11] M. Rosen, B. Lublinsky, K. T. Smith, and M. J. Balcer, Applied SOA Service Oriented Architecture and Design Strategies. Indianapolis, Indiana: Wiley Publishing, Inc, 2008.

[12] Menkes, Keputusan Menteri Kesehatan RI No. 43/Menkes/SK/II/1988 tentang Pedoman Cara Pembuatan Obat yang Baik. 1988.

[13] BPOM, keputusan Kepala Badan POM Nomor HK.00.053.0027. 2006.

[14] D. R. Cooper and P. S. Schindler, Business Research Methods, 12th ed. McGraw-Hill Education, 2013.

[15] H. Rojas, K. A. Arias, and R. Renteria, "Service-oriented architecture design for small and medium enterprises with infrastructure and cost optimization.," Procedia Comput. Sci., vol. 179, pp. 488-497, 2021, doi: 10.1016/j.procs.2021.01.032. 